\title{
Communal nests of Hemidactylus mabouia (Moreau de Jonnès, 1818) (Squamata: Gekkonidae) in a remnant of Atlantic Forest in northeastern Brazil
}

\author{
Pablo Augusto Gurgel de Sousa ${ }^{1,2 *}$ \\ Eliza Maria Xavier Freire ${ }^{1}$ \\ ${ }^{1}$ Laboratório de Herpetologia, Departamento de Botânica, Ecologia e Zoologia \\ Centro de Biociências, Universidade Federal do Rio Grande do Norte \\ Campus Universitário Lagoa Nova, CEP 59072-970, Natal - RN, Brazil \\ ${ }^{2} \mathrm{PPG}$ em Psicobiologia, Centro de Biociências \\ Universidade Federal do Rio Grande do Norte \\ *Author for correspondence \\ pabloguitar2@hotmail.com
}

Submetido em 11/02/2010

Aceito para publicação em 12/05/2010

\section{Resumo}

Ninhos comunais de Hemidactylus mabouia (Squamata: Gekkonidae) em remanescente de mata atlântica no nordeste do Brasil. Ninhos comunais têm sido registrados para várias espécies de lagartos. Essas agregações de ovos oferecem potenciais vantagens, tais como proteção, saciedade a predadores e termorregulação. Hemidactylus mabouia é uma espécie colonizadora de sucesso que apresenta reprodução contínua e tamanho fixo de ninhada, produzindo dois ovos de cada vez. Relatamos aqui o registro de dois ninhos comunais de Hemidactylus mabouia para o Parque Estadual Mata da Pipa, mata atlântica do nordeste do Brasil.

Unitermos: Gekkonidae, Lacertilia, Mata Atlântica, ninho comunal, reprodução

\section{Abstract}

Communal nests of Hemidactylus mabouia (Moreau de Jonnès, 1818) (Squamata: Gekkonidae) in a remnant of Atlantic Forest in northeastern Brazil. Communal nesting has been registered for several species of lizards. The egg aggregations offer potential advantages such as protection, predator-satiation and thermoregulation. Hemidactylus mabouia is a successful colonizing species with continuous reproduction and a fixed size of two eggs each time. Here, we report two communal nests of Hemidactylus mabouia for the Parque Estadual Mata da Pipa, Atlantic Forest of northeastern Brazil.

Key words: Atlantic Forest, communal nest, Gekkonidae, Lacertilia, reproduction

Communal oviposition, egg laying or nesting, as defined by Espinoza and Lobo (1996), are "the nonincidental deposition of eggs at a shared nest cavity by two or more co-specifics". Rand (1967) suggests that this behavior may be due to the relative scarcity of suitable sites, leading the species to a multiple use of those available. Communal nesting has been reported to occur in numerous saurian taxa, (Graves and Duvall, 1995; Espinoza and Lobo, 1996) such as species of Anolis (Rand, 1967), teiids (e.g. Kentropyx calcarata; 
Magnusson and Lima, 1984), gymnophtalmids (e.g. Neusticurus ecpleopus; Magnusson and Lima, 1984), and several geckos (Vitt et al., 1997). The number of eggs encountered in communal nests depends on the species involved. Communal nestings of some teiids, like Kentropyx calcarata, can contain more than 800 eggs (Magnusson and Lima, 1984) and the sphaerodactylid Gonatodes humeralis can lay more than fifty eggs in a single nest (Vitt et al., 1997).

Hemidactylus mabouia is an exotic species, coming from Africa; it was probably introduced by slave ships in Brazil, where it occurs throughout its length (Vanzolini, 1978), occupying natural habitats and disturbed areas. This species has a fixed size of nest, producing two eggs each time, and its reproduction is continuous (Vitt, 1986; Meshaka et al., 1994; Anjos and Rocha, 2008a). Communal nests of this species were recorded for South America by Bock (1996) in Colombia. We report here two communal nests of Hemidactylus mabouia from the Brazilian Atlantic Forest.

At $1330 \mathrm{~h}$ on 11 July 2009, during a study of the structure of a lizard assemblage in the Parque Estadual Mata da Pipa (PEMP), municipality of Tibau do Sul, state of Rio Grande do Norte, Brazil $\left(6.24861^{\circ} \mathrm{S}, 35.05750^{\circ} \mathrm{W}\right.$, datum: WGS84; elev. 63m - Figure 1), on a hot day $\left(27^{\circ} \mathrm{C}\right)$ during the rainy season, one of us (PAGS) found the first communal nest (12 eggs) under the bark of a trunk in decomposition (local temperature of $31.4^{\circ} \mathrm{C}$ and at $10 \mathrm{~cm}$ to the ground, $29.3^{\circ} \mathrm{C}-$ Figure 2). At 0920 $\mathrm{h}$ on 4 November 2009, during the dry season, the same person found the second communal nest (14 eggs) among tiles stacked at the forest's edge (local temperature of $32.7^{\circ} \mathrm{C}$ and at $10 \mathrm{~cm}$ to the ground, $30.1^{\circ} \mathrm{C}-$ Figure 3 ).

All eggs found were very similar in color (white), size (approximately $0.6 \mathrm{~cm}$ in length and $0.25 \mathrm{~cm}$ in width), and texture. In the fist nest, seven eggs had hatched; in the second, two. To determine the period of incubation of the others, one egg in each nest was opened; the newborn has moved itself and went to a secluded place (nearby decomposing trunks). This procedure was repeated for the remaining eggs with the same attitude, and we confirmed that these were specimens of H. mabouia. None of the specimens were collected.

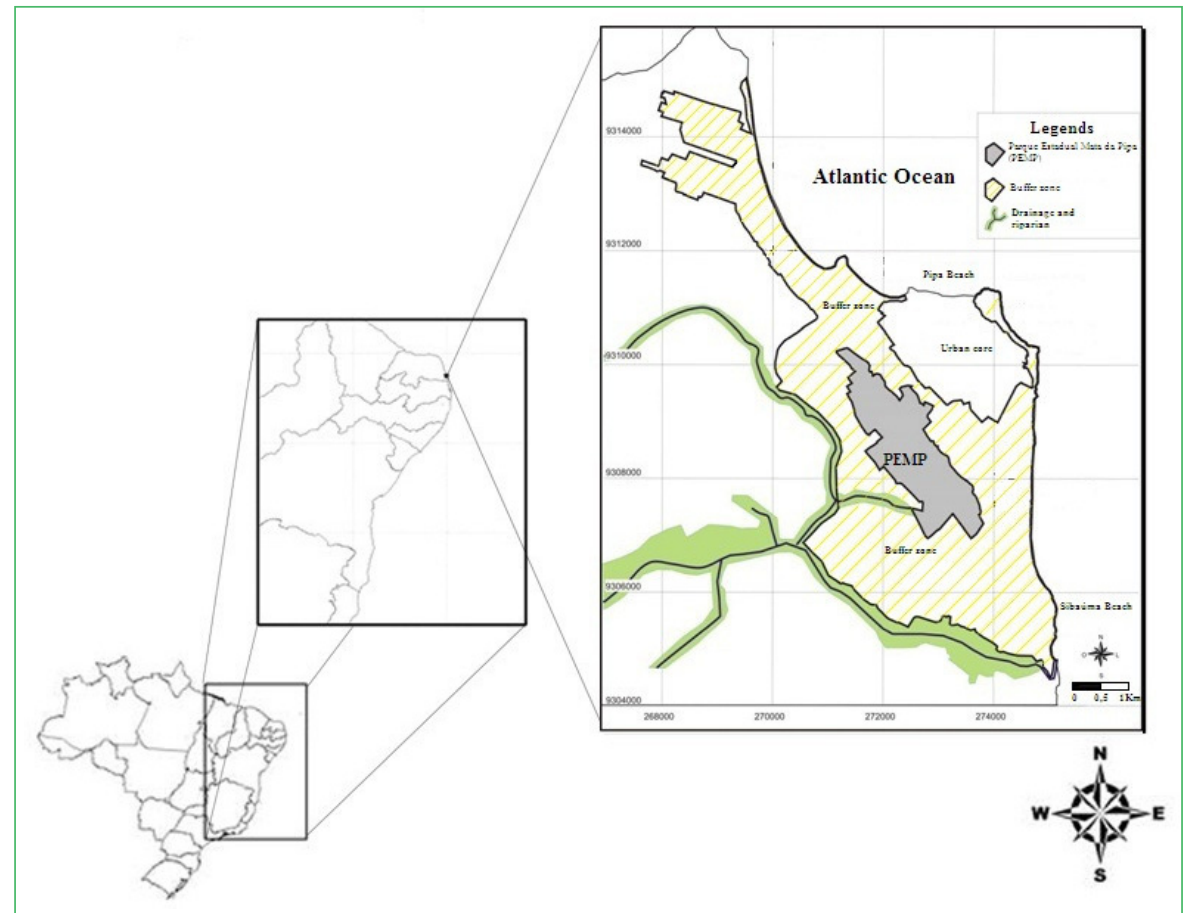

FIGURE 1: Schematic map of the place of registration; The Parque Estadual Mata da Pipa, state of Rio Grande do Norte, Brazil. 


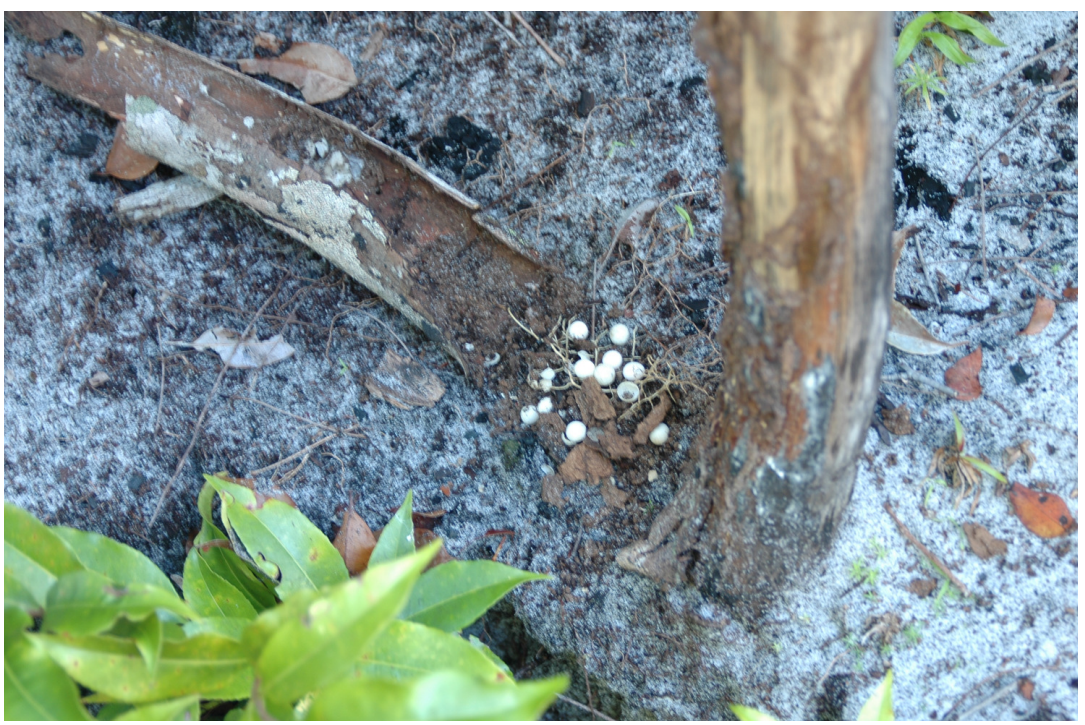

FIGURE 2: The communal nest found under the bark of a decaying trunk, composed by 12 eggs.

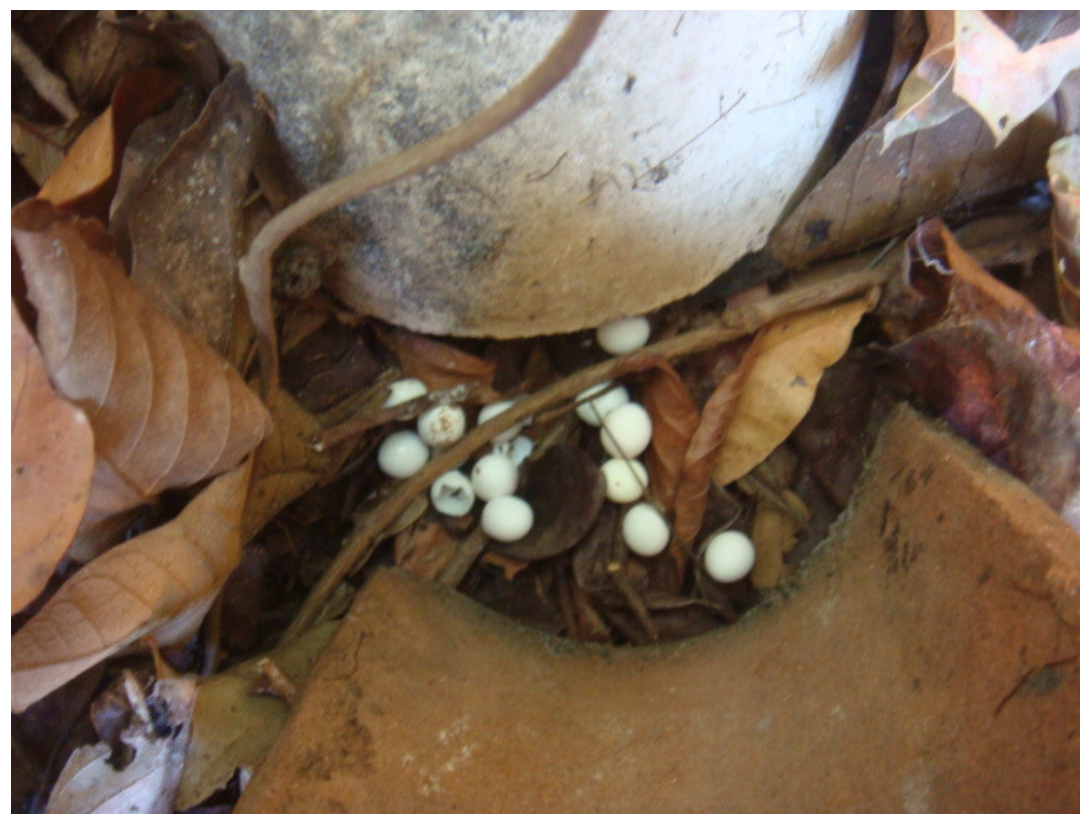

FIGURE 3: The communal nest found between two tiles, composed by 14 eggs.

Many reptiles deposit eggs in large clutches. Because Gekkonidae, Phyllodactylidae and Sphaerodactylidae females oviposit only one or two eggs each time, communal nesting may effectively be creating a combined larger clutch size. Subsequently, these egg aggregations offer potential advantages such as protection (Jackson, 1989), predator-satiation (Eckrich and Owens, 1995), and thermoregulation (Booth and Astill, 2001). Hemidactylus mabouia is a successful colonizing species (Meshaka et al., 1994; Meshaka,
2000; Anjos and Rocha, 2008b); knowledge of the reproductive strategies of invasive species is crucial to understanding their success and can be useful in controlling a population that is already established (Whittier and Limpus, 1996).

\section{Acknowledgements}

We are grateful to the Conselho Nacional de Desenvolvimento Científico e Tecnológico (CNPq) 
for the research scholarship granted to PAGS (process 127543/2008-2) and EMXF (process 304077/2008-9), and to David Maurice Hasset, owner of the Santuário Ecológico de Pipa, for providing us with hosting.

\section{References}

Anjos, L. A.; Rocha, C. F. D. 2008a. Reproductive ecology of the invader species gekkonid lizard Hemidactylus mabouia in an area of southeastern Brazil. Iheringia, Série Zoologia, 98 (2): 205-209. Anjos, L. A.; Rocha, C. F. D. 2008b. A lagartixa Hemidactylus mabouia Moreau de Jonnès, 1818 (Gekkonidae): uma espécie exótica e invasora amplamente estabelecida no Brasil. Natureza \& Conservação, 6: 78-89.

Bock, B. C. 1996. Interclutch interval and egg aggregations in the tropical house gecko Hemidactylus mabouia. Herpetological Review, 27: 181-183.

Booth, D. T.; Astill, K. 2001. Temperature variation within and between nests of the green sea turtle, Chelonia mydas (Chelonia: Cheloniidae) on Heron Island, Great Barrier Reef. Australian Journal of Zoology, 49: 71-84.

Eckrich, C. E.; Owens, D. W. 1995. Solitary versus arribada nesting in the olive ridley sea turtles (Lepidochelys olivacea): A test of the predator-satiation hypothesis. Herpetologica, 51: 349-354.

Espinoza, R. E.; Lobo, F. 1996. Possible communal nesting in two species of Liolaemus lizards (Iguania: Tropiduridae) from northern Argentina. Herpetological Natural History, 4: 65-68.
Graves, B. M.; Duvall, D. 1995. Aggregation of squamate reptiles associated with gestation, oviposition, and parturition. Herpetological Monographs, 9: 102-119.

Jackson, D. 1989. Turtles' use of alligator nests. In: Ross, C. A. (Ed.). Crocodiles and Alligators. Merehurt Press, London, UK, p. $145-170$.

Magnusson, W.; Lima, A. 1984. Perennial communal nesting by Kentropyx calcaratus. Journal of Herpetology, 18 (1): 73-75.

Meshaka, W. E. 2000. Colonization dynamics of two exotic geckos (Hemidactylus garnotii and H. mabouia) in Everglades National Park. Journal of Herpetology, 34 (1): 163-168.

Meshaka, W. E.; Butterfild, B. P.; Hauge, J. B. 1994. Reproductive notes on the introduced gecko Hemidactylus mabouia in southern Florida. Herpetological Natural History, 2 (1): 109-110.

Rand, A. S. 1967. Communal egg laying in anoline lizards. Herpetologica, 23: 227-231.

Vanzolini, P. E. 1978. On South American Hemidactylus (Sauria, Gekkonidae). Papéis Avulsos de Zoologia, 31: 307-343.

Vitt, L. J. 1986. Reproductive tactics of sympatric gekkonid lizards with a comment on the evolutionary and ecological consequences of invariant clutch size. Copeia, 3: 773-786.

Vitt, L. J.; Zani, P. A.; Barros, A. A. M. 1997. Ecological variation among populations of the gekkonid lizard Gonatodes humeralis in the Amazon Basin. Copeia, 1997: 32-43.

Whittier, J. M; Limpus, D. 1996. Reproductive patterns of a biologically invasive species: The Brown tree snake (Boiga irregularis) in eastern Australia. Journal of Zoology, 238: 591597. 